\title{
Microclimatic characterization and productivity of coffee plants grown under shade of pigeon pea in Southern Brazil
}

\author{
Heverly Morais ${ }^{(1)}$, Paulo Henrique Caramori(1) Ana Maria de Arruda Ribeiro(2), José Carlos Gomes $^{(1)}$ \\ and Mirian Sei Koguishi(1)
}

\begin{abstract}
(1)Instituto Agronômico do Paraná, Rod. Celso Garcia Cid, Km 375, Caixa Postal 481, CEP 86001-970 Londrina, PR, Brazil. E-mail: heverly@iapar.br, caramori@iapar.br, jcgomes@iapar.br, miriansei@iapar.br(2)Universidade Estadual de Londrina, Centro de Ciências Agrárias, Dep. de Agronomia, Caixa Postal 6001, CEP 86051-990 Londrina, PR, Brazil. E-mail: arruda@uel.br
\end{abstract}

\begin{abstract}
Recent studies on coffee (Coffea arabica L.) cultivation in agroforestry systems in Southern Brazil have shown the potential of partial shading to improve management of this crop. The objective of this work was to evaluate microclimatic conditions and their effects on coffee production of plants shaded with pigeon pea (Cajanus cajan) in comparison to unshaded ones, from May 2001 to August 2002 in Londrina, State of Paraná, Brazil. The appraised microclimatic characteristics were: global radiation, photosynthetic and radiation balance; air, leaf and soil temperatures; and soil humidity. Shading caused significant reduction in incident global solar radiation, photosynthetically active radiation and net radiation, and attenuated maximum leaf, air and soil temperatures, during the day. Shade also reduced the rate of cooling of night air and leaf temperatures, especially during nights with radiative frost. Soil moisture at 0-10 cm depth was higher under shade. The shaded coffee plants produced larger cherries due to slower maturation, resulting in larger bean size. Nevertheless, plants under shade emitted less plagiotropic branches, with smaller number of nodes per branch, and fewer nodes with fruits, resulting in a large reduction in coffee production. These results show the need to find an optimal tree density and management that do not compromise coffee production and protect against extreme temperatures.
\end{abstract}

Index terms: Coffea arabica, Cajanus cajan, frost protection, photosynthetically active radiation, coffee production, shade.

\section{Caracterização microclimática e produtividade de cafeeiros sombreados com guandu no Sul do Brasil}

\begin{abstract}
Resumo - Recentes estudos sobre cafeeiros (Coffea arabica L.) cultivados em sistemas agroflorestais no Sul do Brasil têm mostrado o potencial do sombreamento parcial no manejo desta cultura. O objectivo deste trabalho foi avaliar as condições do microclima e seus efeitos na produção de café sombreado com guandu (Cajanus cajan), em comparação ao cultivado a pleno sol, no período de maio de 2001 a agosto de 2002 em Londrina, PR. As características microclimáticas avaliadas foram: radiação global, fotossintética e saldo de radiação; temperaturas do ar, da folha e do solo; e umidade do solo. O sombreamento causou significativa redução na radiação solar global incidente, na radiação fotossinteticamente ativa e na radiação líquida, e atenuou as temperaturas máximas foliar, do ar e do solo, durante o dia. O sombreamento também evitou o declínio acentuado, durante a noite, das temperaturas do ar e da folha, especialmente durante noites com geadas de radiação. Os valores de umidade do solo, na camada $0-10 \mathrm{~cm}$ de profundidade, foram maiores nos cafeeiros sombreados. As plantas sombreadas produzem frutos maiores em virtude da maturação mais lenta, entretanto, emitem menos ramos plagiotrópicos, com menor número de nós por ramo e poucos nós com frutos, o que resulta na redução da produção de café. Estes resultados evidenciam a necessidade de se definir uma densidade ótima de sombreamento, que não comprometa a produção e proteja contra as temperaturas extremas.
\end{abstract}

Termos para indexação: Coffea arabica, Cajanus cajan, proteção contra geada, photosynthetically active radiation, produção de cafeeiros, sombreamento.

\section{Introduction}

Intercropping coffee with different tree species is a very promising practice due to many benefits that can be derived from this system. Studies of the structure and dynamics of coffee agroforestry systems have shown the importance of shading to improve soil and microclimatic conditions for coffee plants (Barradas \& 
Fanjul, 1986; Babbar \& Zak, 1995; Campanha et al., 2004). Shade trees can help maintain soil fertility by fixing nitrogen from the atmosphere, to increase soil organic matter through the biomass inputs of roots and aerial parts, and to mitigate nutrient loss (Babbar \& Zak, 1995). Shading also provides a microclimate which attenuates air and soil extreme temperature, preserves surface soil humidity and protects coffee from the impact caused by rain, hail and winds.

In Southern Brazil, protection against radiative frosts is an additional advantage of this system (Caramori et al., 1999). Severe frosts which damage coffee plantations occur roughly every 5-6 years, between June and August, in the States of São Paulo and Paraná (Caramori et al., 1996). However, the main reason to use an agroforestry system in a coffee plantation is its potentially positive effect on coffee production.

Crop productivity is linked to the efficiency of the utilization of photosyntheticaly active radiation (PAR) (Barradas \& Fanjul, 1986). There is some controversy over whether coffee trees are more productive when cultivated under full sunlight, or shaded, but it is generally accepted that shade stabilizes growth by reducing the excess production, which is observed in open-grown plantations in some years (Kumar \& Tieszen, 1980). Both from the productive and the ecological points of view, knowledge of the microclimatic changes in shaded systems through the crop cycle, and in different periods of the year, is important to establish agronomical and sustainable practices.

The choice of tree to be used in the system is a key step for the success of this practice. It must be made according to the objective of the system, the site conditions (soil and climate) and the species adaptability to the region. Aiming at protecting coffee against frost, the species Grevillea robusta, Mimosa scabrella, Leucaena leucocephala, Hevea brasiliensis and banana (Caramori et al., 2004) have been used in Brazil with satisfactory results. Pigeon pea (Cajanus cajan) has a high potential as an agroforestry component in coffee plantations, because it protects young coffee plantations from frosts (Caramori et al., 1999) and winds, fixes nitrogen symbiotically from the atmosphere, and improves soil structure and fertility, through the deposition of leaves and recycled nutrients (Seiffert et al., 1988).

The objective of this work was to evaluate the microclimatic changes and their effects on the production of coffee shaded with pigeon pea (Cajanus cajan) compared to an adjacent open-grown plot in Southern Brazil.

\section{Material and Methods}

The work was carried out in the experimental farm of the Instituto Agronômico do Paraná (Iapar), PR, Brazil, at $23^{\circ} 23^{\prime} \mathrm{S}, 50^{\circ} 11^{\prime} \mathrm{W}$ and altitude of $610 \mathrm{~m}$. The site was facing West with $5 \%$ slope. The soil is a Rhodic Ferralsol (Haplorthox), with 82\% clay, 13\% silt and $5 \%$ sand. The climate of the region is Cfa, in the Köppen classification. The annual average temperature is $21^{\circ} \mathrm{C}$, with a monthly mean of $24^{\circ} \mathrm{C}$ in January, the warmest month, and $17^{\circ} \mathrm{C}$ in July, the coldest month. The annual precipitation average is 1,630 mm, with December, January and February as the rainiest months, and June, July and August, as the driest (Caviglione et al., 2000).

Seedlings of Coffea arabica cultivar IPR99 were planted on December $10^{\text {th }}, 1998$ on a grid $2.5 \times 0.7 \mathrm{~m}$, with one plant per pit, and were pruned in September, 2000 at $30 \mathrm{~cm}$ height, after a severe frost. All the practical recommendations for the management of a commercial coffee crop were adopted (Matiello et al., 2002).

The experiment was carried from December 2000 to August 2002. The experimental area occupied 6,000 m², split in two sub-areas containing coffee trees cultivated under sunlight and intercropped with giant pigeon pea (Cajanus cajan), cultivar IAPAR PPP-832. The pigeon pea was sown in the inter-row of the coffee plants, with three plants per linear meter, in December 2000, reaching its maximum height (about $4 \mathrm{~m}$ ) on May 2001, when the canopy closed completely to shade the coffee plants. On September 2001, the pigeon pea was pruned at $60 \mathrm{~cm}$ height, and started another growing cycle, reaching its maximum height in April 2002.

The microclimate was continuously monitored both in shaded and unshaded conditions from May 2001 to August 2002, except for September 2001, when there was an equipment malfunction. The following variables were measured: global solar radiation, measured with silicon pyranometers (LI-COR, Model LI200X); photosynthetic active radiation (PAR), measured with silicon quantum sensors (LI-COR, Model LI190SB); net radiation, measured with net radiometers (REBS, Q*7.1), with spectral response between 0.25 and $60 \mu \mathrm{m}$; all radiation sensors were installed between two coffee plants, in the row, at the approximate height of the upper coffee canopy ( $1 \mathrm{~m}$ in the first year, and $1.5 \mathrm{~m}$ in the second year); the percentages of radiation intercepted by the pigeon pea were calculated relatively to the 
unshaded condition; air temperature - two copperconstantan thermocouple sensors were installed in the coffee rows, between two plants, $50 \mathrm{~cm}$ height (to protect the thermocouples from direct exposure to the sun, they were covered with PVC tubes of $5 \mathrm{~cm}$ diameter cut in halves, with $10 \mathrm{~cm}$ length); leaf temperature - two copper-constantan thermocouple sensors were installed, in touch with the abaxial part of leaves from the second pair of the plagiotropic branch, counted from the stem tip, facing north and on the median region of the coffee plants; thermal amplitude was calculated as the difference between maximum and minimum temperatures; soil temperature, measured with thermistor sensors, located in a position equivalent to the average extremity of the lower plagiotropic branches of two representative coffee plants, at $10 \mathrm{~cm}$ depth in the soil; soil moisture - surface layer moisture $(0-10 \mathrm{~cm})$ was monitored weekly with four replications, between April and October 2001, using the gravimetric method. Daily precipitation was collected at a weather station located $100 \mathrm{~m}$ from the experimental area.

In the center of each plot, an automatic meteorological station was installed. The sensors were connected to a micrologger (Campbell Sci., Datalogger 21X), and all the meteorological parameters described above were collected every 10 seconds and averaged over 10 minutes for storage. Monthly averages of radiation were obtained from daily totals.

Tem plants of each treatment were randomly chosen, and the following variables were evaluated: number of plagiotropic branches, number of branches with fruits, number of nodes per branch, number of nodes with fruits per branch, and the total number of fruits per branch.

Coffee production in the shaded and unshaded environments was evaluated on June $15^{\text {th }}$, 2002, in terms of maturation, grain size and grain weight. A total of 50 plants, in five sub-samples of 10 plants, were harvested in each treatment.

The data were submitted to average comparison with the Student t-test, at 5 and $1 \%$ of probability. The following procedures were adopted for each parameter evaluated: fruit maturation - samples of $300 \mathrm{~g}$ of fruit were taken from each replication to count the number of fruits that were green, mature or dry; coffee grain weight - fresh coffee cherry weight (immediately after harvesting), dry coffee cherry weight, and clean coffee weight (after removing the pulp) were evaluated (to obtain the dry coffee weight, the fruits were dried in a stove for 2 days at $55^{\circ} \mathrm{C}$ ); coffee grain size - the total production of clean coffee from each environment was homogenized, and samples of $200 \mathrm{~g}$ of beans were collected and taken to a vibratory electric machine, containing trays with meshes of $18,17,16,15,14,13$ and $12 \mathrm{~mm}$ diameter. The $12 \mathrm{~mm}$ bolter retained the "moca" beans that originated, by genetic variability, the monocotyledon grains. Grains not retained on the bolters were stored on a tray called "bottom", situated on the base of the machine. The coffee grains on the different meshes were weighed separately, and the values were converted to percentage of total bean weight, before statistical analyses were performed. Seeds of pigeon pea were not harvested.

\section{Results and Discussion}

The incident global solar radiation, PAR and net radiation were greatly reduced under the pigeon pea, due to the interception of solar radiation by plants (Figure 1). The maximum shading ocurred during the winter, reducing global radiation by $87 \%$, PAR by $79 \%$ and net radiation by $91 \%$. During the year, these variables showed gradual variation related to seasonal variation in solar energy and pigeon pea development. One month after the pigeon pea pruning (October), the global solar radiation was approximately $4 \mathrm{MJ} \mathrm{m}^{-2}$ day $^{-1}$ lower under shade, showing the fast vegetative development of pigeon pea at this site. In the first cropping year, the shading was greatest during the winter, indicating that after the first pruning the vegetative vigor of pigeon pea decreased (Figure $1 \mathrm{~A}$ and $\mathrm{C}$ ). Willey (1975) observed that excess shade reduced the quantity and the quality of light that reaches the plants.

Shading reduced the mean air and leaf temperatures, during most of the experimental period, especially during winter, due to dense vegetative covering established over the coffee plants (Figure 2). A reduction of high temperatures can be favorable for C. arabica development. Visible symptoms of damage are caused by over-heating and excess radiation intensity (Willey, 1975). Mes (1957) observed deficient floral development, and a large number of aborted flowers, when air temperatures were high $\left(30^{\circ} \mathrm{C}\right.$ during the day, and $24^{\circ} \mathrm{C}$ during the night).

Air and leaf maximum and minimum temperatures, during the period of evaluation, showed similar tendencies in both treatments, but the magnitude differed (Figure 2). There was a greater effect on maximum temperatures, with higher differences between 
environments during the winter (when the shading was dense), and during the months of March and April of 2002 (the warmest period observed during the experiment). During June of 2001, the average maximum temperature of the open-grown leaves was $25.5^{\circ} \mathrm{C}$, $4^{\circ} \mathrm{C}$ higher than the average values observed in the shaded leaves. During the warmest period, the average maximum air temperature was 40.5 and $36.0^{\circ} \mathrm{C}$, under
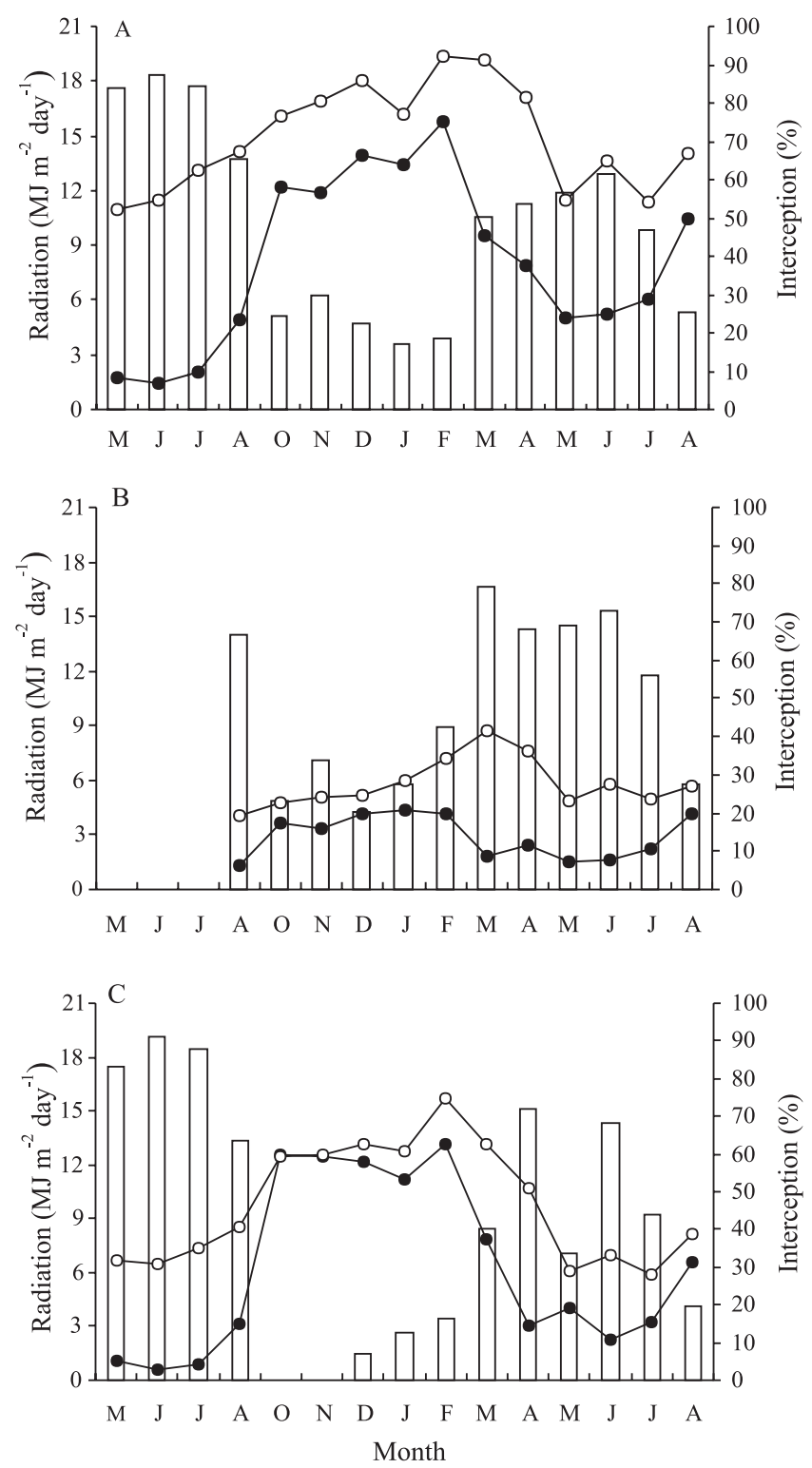

Figure 1. Monthly distribution of global solar radiation (A), photosynthetically active radiation - PAR (B), and net radiation (C), from May, 2001 to August, 2002 (except September, 2001), on shaded (closed circles) and unshaded environments (opened circles). The columns correspond to the percentage of radiation intercepted by the pigeon pea. full sunlight and shade, respectively. The minimum temperature differences between shaded and unshaded environments were lesser during spring and summer, and higher during autumn and winter. Miguel et al. (1995) also reported a reduction of maximum and elevation of minimum temperatures, in a coffee plantation shaded with Grevillea robusta, with beneficial effects to the coffee plants.
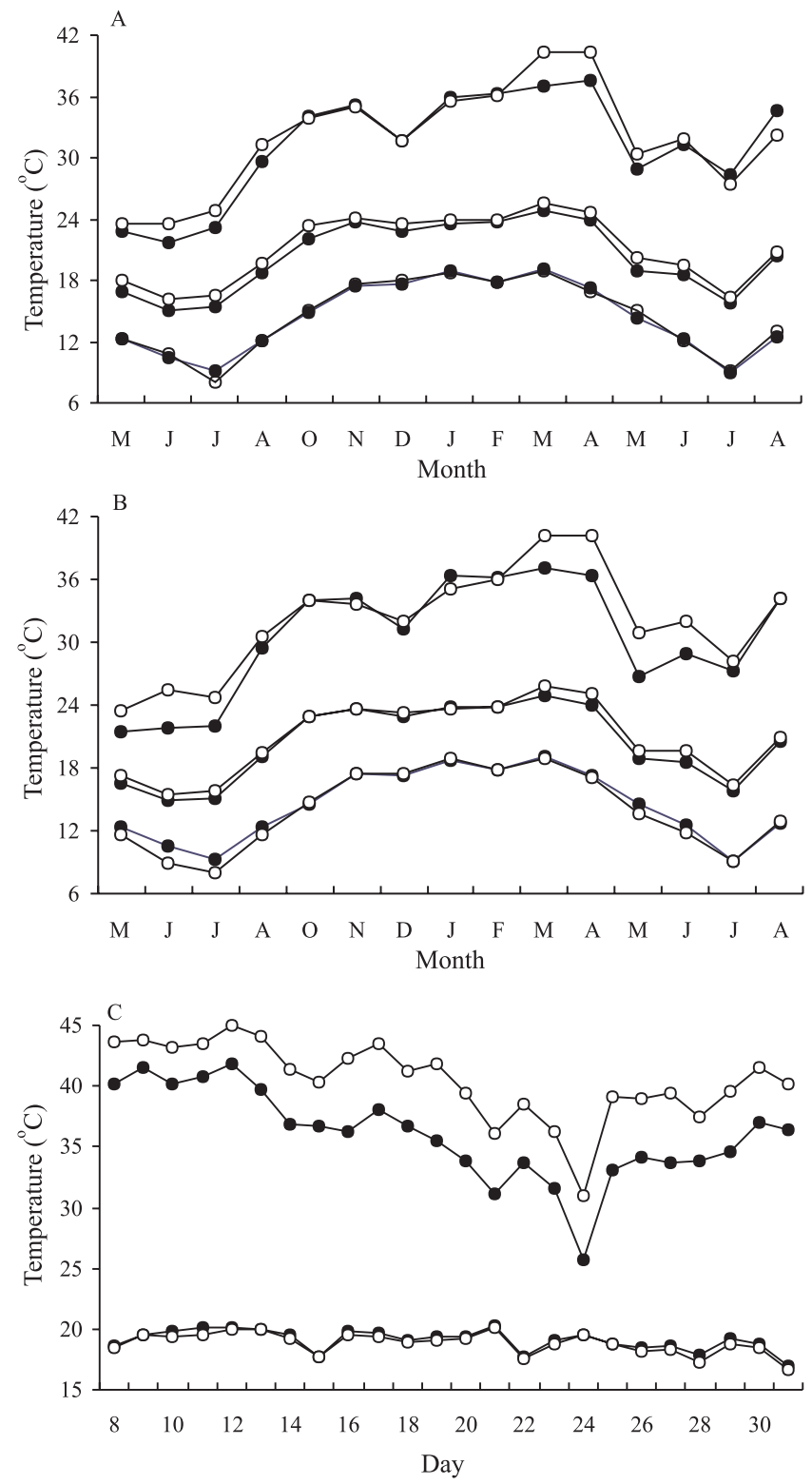

Figure 2. Monthly distribution of air maximum, mean and minimum temperatures (A), leaf temperature (B), from May 2001 to August, 2002 (except September, 2001), and daily distribution of air maximum and minimum temperatures during March, 2002 (C) on shaded (closed circles) and unshaded (opened circles) environments. 
The average difference between daily maximum and minimum leaf temperatures was $18.1^{\circ} \mathrm{C}$, in the opengrown plants, and $16.0^{\circ} \mathrm{C}$ in the shaded ones. The smaller temperature difference under shade occurred because of the maximum temperature decrease (Figures 2 and 3). Thermal amplitude is strictly related to shade density, as can be seen by the small difference between the treatments that occurred during the senescence stage of the pigeon pea and after its pruning. Barradas \& Fanjul (1986) also reported smaller differences of temperature in shaded coffee.

The soil temperature was always lower in the shaded plot, with greater differences between treatments occurring from October to April, when air temperature was the highest (Figure 4). The constant attenuation of soil temperature, independent of the variations on shade density, was due to the reduction of the soil heat flux caused by the accumulated phytomass (roots, stems and leaves). Barradas \& Fanjul (1986) also reported lower soil temperatures in a shaded coffee plantation. The soil stabilizes the local thermal balance, absorbing a considerable quantity of heat during the day and returning it to the atmosphere during the night. Over a vegetated area, this stabilization is more efficient, with less thermal oscillations, because during the day the vegetation protects the soil surface against radiation that causes excessive heating, and during the night it minimizes thermal radiation loss (Larcher, 2000).

During the experiment, a series of frosts occurred from June $20^{\text {th }}$ to June $23^{\text {rd }}$, 2001. The minimum leaf temperatures measured on the open-grown coffee leaves were $-1.1^{\circ} \mathrm{C}$ on the $20^{\text {th }},-0.6^{\circ} \mathrm{C}$ on the $21^{\text {st }}$, and $-0.3^{\circ} \mathrm{C}$ on the $22^{\text {nd }}$, with a thin layer of ice deposition on the

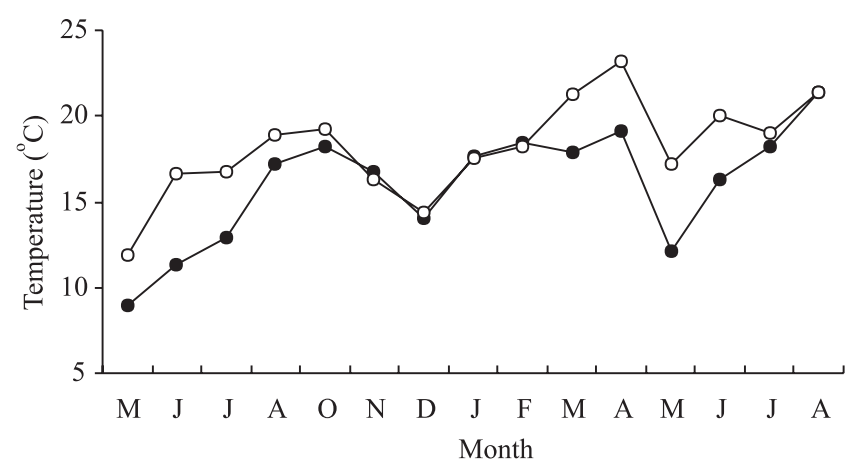

Figure 3. Monthly distribution of leaf thermal amplitude in 2001 and 2002 (except September, 2001), in shaded (closed circles) and unshaded (opened circles) environments. exposed surfaces, characterizing a weak radiative frost (Figure $5 \mathrm{~A}$ and $\mathrm{B}$ ). In the shaded treatment, the minimum leaf temperatures were $3.8,0.8$ and $1.3^{\circ} \mathrm{C}$ from $20^{\text {th }}$ to $22^{\text {nd }}$, respectively. The higher temperatures observed on the shaded coffee plants were due to the interception and emission of longwave radiation by the pigeon pea canopy.

During the winter, the shaded coffee exhibited smaller thermal amplitude. During the day, the pigeon pea attenuated the maximum temperatures, with an average reduction of $4.8^{\circ} \mathrm{C}$ (Figure $5 \mathrm{~A}$ ). Similar behavior was also reported by Barradas \& Fanjul (1986), who saw a reduction of $5.4^{\circ} \mathrm{C}$ of the maximum air temperatures in a coffee plantation shaded with Inga junicuil. The shading reduced the rate of air and leaf temperature decreased at night, with minimum air temperatures 1 to $4^{\circ} \mathrm{C}$ higher under the pigeon pea shade, compared to the coffee plants without shade (Figure $5 \mathrm{~B}$ ). This occurred due to the downward emissions from the pigeon pea canopy and the reduction of thermal radiation loss from the surface of coffee leaves to the atmosphere under shade. Caramori et al. (1999), studying methods of protecting new planted coffee against frost, found increases of up to $5.5^{\circ} \mathrm{C}$ in the daily minimum temperature of coffee leaves shaded with pigeon pea, suggesting that this species is one with great potential to minimize the impacts of severe frosts on coffee plantations in Southern Brazil. Higher night temperatures in shaded environments were also reported by Caramori et al. (1996).

The daily cycle of net radiation also had a significant reduction in amplitude in the shaded plot, with positive nightly values, during the whole experimental period. In

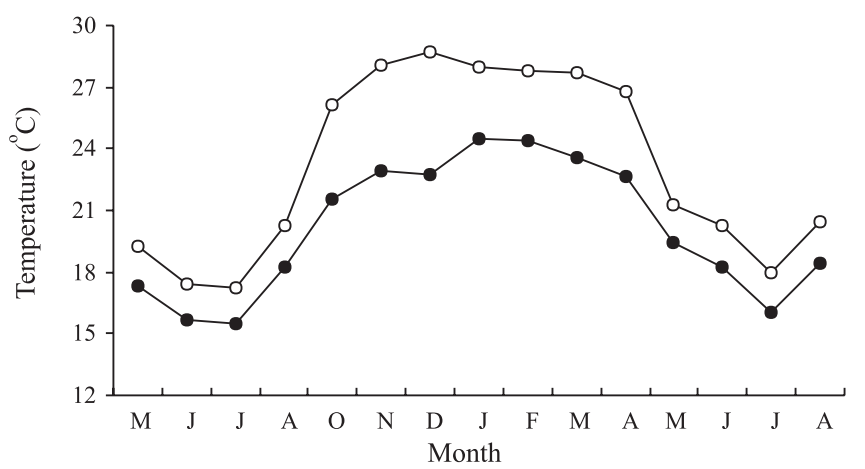

Figure 4. Monthly distribution of soil temperature at $10 \mathrm{~cm}$ depth, from May, 2001 to August, 2002 (except September, 2001), on shaded (closed circles) and unshaded (closed circles) environments. 
contrast, the unshaded area had negative net radiation values during cloudless nights (Figure $5 \mathrm{C}$ ). The reduction of radiation loss in the shaded plot, and the greater downward radiation from the overstory contributed to reduce minimum temperatures, during the night period, with positive impacts in frost protection. Caramori et al. (1999) also detected smaller losses of long wave radiation on shaded coffee plantations in Southern Brazil.
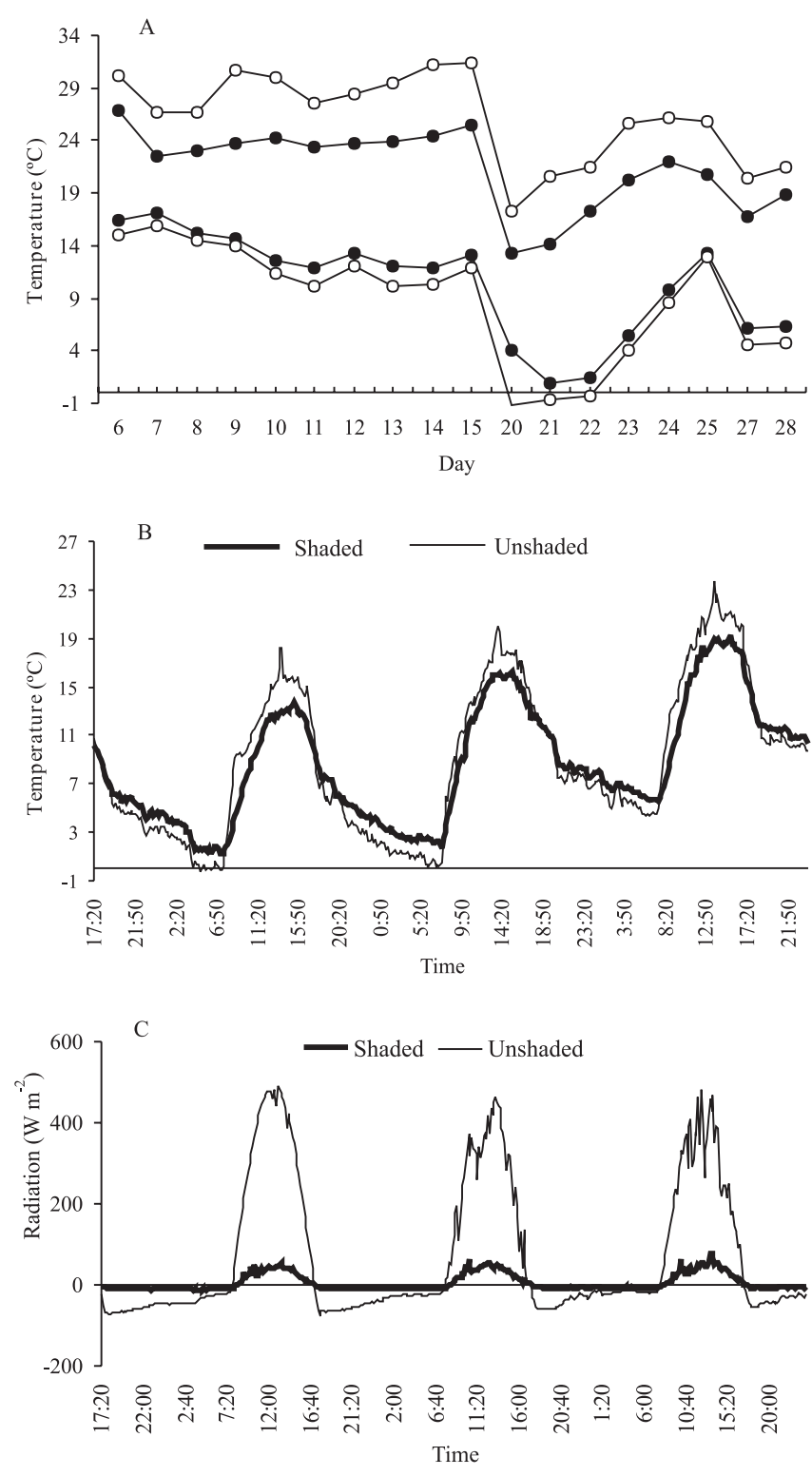

Figure 5. Daily distribution of air maximum and minimum temperatures in June, 2001 (A), on shaded (closed circles) and unshaded (opened circles) environments, and leaf temperature (B) and net radiation (C) from June $20^{\text {th }}$ to June 23rd, 2001.
Soil moisture in the surface layer $(0-10 \mathrm{~cm})$ was higher in the shaded environment (Figure 6), possibly due to the "mulching" from leaves and branches of the pigeon pea (and of the coffee plants), and to the attenuation of incident solar radiation by the canopy of pigeon pea. The litter layer reduced evaporative loss of soil water, while the shading decreased the energy available for evaporation (Beer, 1992). Suárez de Castro et al. (1961) reported that, in El Salvador, during the driest months, the soil moisture was higher in the shaded areas.

There was no difference in the number of branches per plant between treatments. The unshaded plants had more branches with fruit, nodes per branch, nodes with fruit, and total fruit per branch (Table 1). These components are directly related to the production, which decreased with shading due to the low PAR incident on the shaded coffee plants (Figure 1 B). Beer (1992) demonstrated that shading negatively affects the growth of productive branches in coffee.

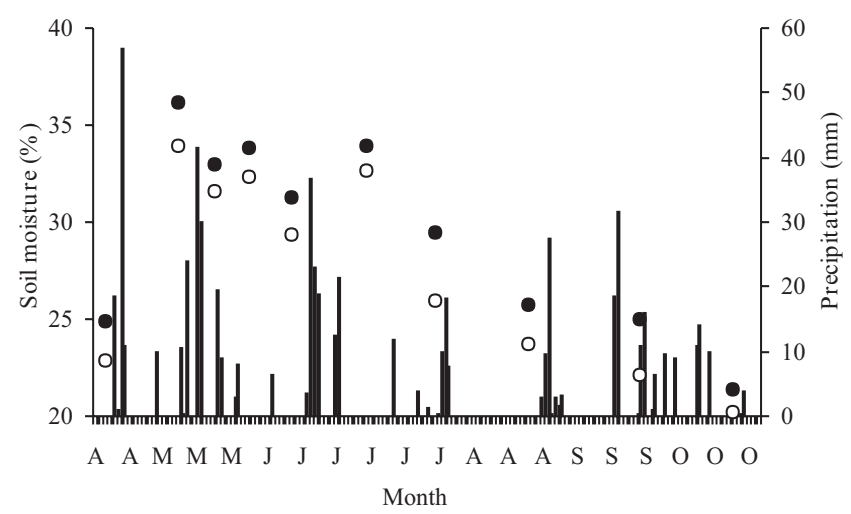

Figure 6. Percentage of volumetric soil moisture in the layer of 0-10 cm, from April to October, 2002, on shaded (closed circles) and unshaded (opened circles) environments. The columns correspond to daily precipitation ( $\mathrm{mm}$ ) in the period.

Table 1. Number of branches, nodes and fruits of Coffea arabica cultivated under pigeon pea (shaded) and full sunlight (unshaded).

\begin{tabular}{|c|c|c|c|}
\hline Cof & Sha & d & $\mathrm{t}$ val \\
\hline Total & 38.20 & 41.30 & $-1.34^{\mathrm{ns}}$ \\
\hline fruits & 12.90 & 22 & -3 \\
\hline $\mathrm{Nu}$ & 16. & 18.59 & $-6.21^{* *}$ \\
\hline & 4.5 & 7.5 & $-7.33^{* *}$ \\
\hline Total & 13.73 & 58.96 & $-11.11^{*}$ \\
\hline
\end{tabular}

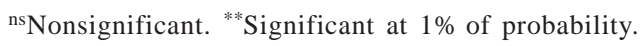


There was no significant difference, between treatments, in the number of green fruits produced (Table 2), but the amount of mature and dry fruits was significantly higher in the unshaded plants, showing the moderate radiation environment provided by shade slowed maturation. Other studies have also shown that shading extends and delays fruit maturation (Miguel et al., 1995). The slower maturation favors the production of fruits of higher quality, since there is an increase on the accumulation of sugar and soluble solids. Vaast \& Harmand (2002) showed that shading enhances coffee quality, in terms of biochemical composition, including the contents of caffeine, oil and chlorogenic acid.

The shaded plants had larger grain size, with $60 \%$ of grains retained on the bolters with meshes of 18 and $17 \mathrm{~mm}$, while grains from the open-grown environment were mostly retained on the bolters of 17 and $16 \mathrm{~mm}$. Further, $28.3 \%$ of the grains produced under shade were retained on the bolters with $18 \mathrm{~mm}$ meshes, compared to only $14.7 \%$ of the open-grown (Table 3). Larger grain size is a favorable characteristic that enhances market value of coffee. These results are in accordance with Carvajal (1984), who also demonstrated that shade enhances coffee grain size.

Table 2. Fruit maturation of Coffea arabica cultivated under pigeon pea shade (shaded) and under full sunlight (unshaded).

\begin{tabular}{lccc}
\hline Maturation characteristics & Shaded & Unshaded & $\mathrm{t}$ value \\
\hline Green fruits & 25.0 & 21.2 & $0.51^{\mathrm{ns}}$ \\
Mature fruits & 19.8 & 34.4 & $6.23^{* *}$ \\
Dry fruits & 40.6 & 59.0 & $-2.56^{*}$ \\
\hline
\end{tabular}

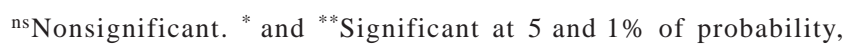
respectively.

Table 3. Clean coffee grains size of Coffea arabica cultivated under pigeon pea shade (shaded) and under full sunlight (unshaded).

\begin{tabular}{cccc}
\hline $\begin{array}{c}\text { Meshes diameter } \\
\text { of the tray }(\mathrm{mm})\end{array}$ & Shaded & Unshaded & t value \\
\hline 18 & 28.19 & 14.73 & $5.42^{* *}$ \\
17 & 32.56 & 33.84 & $-0.85^{\text {ns }}$ \\
16 & 14.67 & 23.15 & $-9.17^{* *}$ \\
15 & 5.08 & 10.31 & $-10.36^{* *}$ \\
14 & 4.48 & 6.06 & $-2.69^{*}$ \\
13 & 0.35 & 0.25 & $1.25^{\text {ns }}$ \\
12 & 12.25 & 9.09 & $6.98^{* *}$ \\
Bottom & 2.52 & 2.87 & $-1.28^{\text {ns }}$ \\
\hline
\end{tabular}

ns Nonsignificant. ${ }^{*}$ and ${ }^{* *}$ Significant at 5 and $1 \%$ of probability, respectively.
The difference in coffee production between treatments was notable. The open-grown plot produced six to seven times more coffee during this first harvest (Table 4). This was due to excessive shade during the two years, which caused a drastic reduction in the PAR level that reached the coffee plants. In Southern Brazil, the period of floral bud development ranges from April to August (Camargo \& Camargo, 2001), when protection against frost is needed. Under low luminosity levels (dense shade), there is inhibition in the development of flower buds, with negative impacts on coffee production. Therefore, it is necessary to further refine this intercropping system, to better balance the needs of frost protection with high production.

Caramori et al. (1996) found higher coffee production under the shade of 250 trees of Mimosa scabrella per hectare - study developed in area located near the present experimental site. Baggio et al. (1997) observed that there was no loss on coffee production with up to 71 trees of G. robusta per hectare (10x14 m of spacing), in the North of Paraná State. In Costa Rica, the production of Bourbon and Caturra with Erythrina poeppigiana were equal or greater than the production under full sunlight with some soil management (Ramírez, 1993). In Colombia, Machado (1959) found advantages of C. arabica var. Typica shaded with Inga spp.

Various other projects have shown that dense shading negatively affected coffee production. The productivity of C. canephora shaded with pigeon pea in Alta Paulista, State of São Paulo, was very low, because of the dense shading of the pigeon pea on the coffee plants (Paulo et al., 2001). Systems of cultivation under full sunlight and with intensive chemical fertilization can be more productive than shaded systems with some soil management (Chamorro et al., 1994). It is important to highlight that it is very difficult to compare productivities obtained in different conditions, because the results are influenced by several factors including tree species used, tree planting density, soil and climatic conditions, coffee

Table 4. Coffee production (g/plot) cultivated under pigeon pea shade (shaded) and under full sunlight (unshaded).

\begin{tabular}{lccc}
\hline Variable analyzed & Shaded & Unshaded & $\mathrm{t}$ value \\
\hline Fresh coffee weight & $1,377.4$ & $8,518.2$ & $-6.59^{* *}$ \\
Dry coffee weight & 623.0 & $4,416.6$ & $-7.75^{* *}$ \\
Clean coffee weight & 350.8 & $2,418.0$ & $-7.61^{* *}$ \\
\hline
\end{tabular}

${ }^{* *}$ Significant at $1 \%$ of probability. 
genotype, crop spacing and the incidence of pests, diseases and weeds. However, it is evident that excessive shading negatively affects coffee production.

\section{Conclusions}

1. Dense shading with Cajanus cajan causes significant impacts on coffee performance in the North of Paraná State, Brazil.

2. Since there is no noticeable competition for water, light competition is the most limiting factor and should be focused on future studies, through definition of management practices related to pruning and spacing of pigeon pea.

\section{References}

BABBAR, L.I.; ZAK, D.R. Nitrogen loss from coffee agroecosystems in Costa Rica: leaching and denitrification in the presence and absence of shade trees. Journal of Environmental Quality, v.24, p.227-233, 1995.

BAGGIO, A.J.; CARAMORI, P.H.; ANDROCIOLI FILHO, A.; MONTOYA, L. Productivity of Southern Brazilian coffee plantations shaded by different stockings of Grevillea robusta. Agroforestry Systems, v.37, p.111-120, 1997.

BARRADAS, V.L.; FANJUL, L. Microclimatic characterization of shaded and open-grown coffee (Coffea arabica L.) plantations in Mexico. Agricultural and Forest Meteorology, v.38, p.101-112, 1986.

BEER, J.W. Production and competitive effects of the shade trees Cordia alliodora and Erythrina poeppigiana in an agroforestry system with Coffea arabica. 1992. 229p. Thesis (Ph.D.) - University of Oxford, Oxford, United Kingdom.

CAMARGO, A.P. de; CAMARGO, M.B.P. de. Definição e esquematização das fases fenológicas do cafeeiro arábica nas condições tropicais do Brasil. Bragantia, v.60, p.65-68, 2001.

CAMPANHA, M.M.; SANTOS, R.H.S.; FREITAS, G.B. de; MARTINEZ, H.E.P.; GARCIA, S.L.R.; FINGER, F.L. Growth and yield of coffee plants in agroforestry and monoculture systems in Minas Gerais, Brazil. Agroforestry Systems, v.63, p.75-82, 2004.

CARAMORI, P.H.; ANDROCIOLI FILHO, A.; LEAL, A.C. Coffee shade with Mimosa scabrella Benth. for frost protection in Southern Brazil. Agroforestry Systems, v.33, p.205-214, 1996.

CARAMORI, P.H.; KATHOUNIAN, C.A.; MORAIS, H.; LEAL, A.C.; GORRETA, R.; ANDROCIOLI FILHO, A. Arborização de cafezais e aspectos climatológicos. In: MATSUMOTO, S.N. (Org.). Arborização de cafezais no Brasil. Vitória da Conquista: Edições Uesb, 2004. p.21-38.

CARAMORI, P.H.; LEAL, A.C.; MORAIS, H. Temporary shading of young coffee plantations with pigeon pea (Cajanus cajan) for frost protection in Southern Brazil. Revista Brasileira de Agrometeorologia, v.7, p.195-200, 1999.

CARVAJAL, J.F. Cafeto, cultivo y fertilización. 2.ed. WorblaufenBern, Suiza: Instituto Internacional de la Potasa, 1984. 254p.

CAVIGLIONE, J.H.; CARAMORI, P.H.; KIIHL, L.R.B.; OLIVEIRA, D. de. Cartas climáticas do Paraná. Londrina: IAPAR, 2000. CD-ROM.

CHAMORRO, G.; GALLO, A.; LOPEZ, R. Evaluación económica del sistema agroflorestal café asociado con nogal. Cenicafé, v.45, p.164-170, 1994.

KUMAR, D.; TIESZEN, L.L. Photosynthesis in Coffea arabica. I. Effects of light and temperature. Experimental Agriculture, v.16, p.13-19, 1980.

LARCHER, W. Ecologia vegetal. Trad. de C.H.B.A. Prado. São Carlos: Rima, 2000. 531p.

MACHADO, S.A. Estado actual de las investigaciones sobre el uso de la sombra en los cafetales. Cenicafé, v.10, p.5-15, 1959.

MATIELLO, J.B.; SANTINATO, R.; GARCIA, A.W.R.; ALMEIDA, S.R.; FERNANDES, D.R. Cultura de café no Brasil - novo manual de recomendações. Rio de Janeiro: Mapa/Procafé, 2002. 387p.

MES, M.G. Studies on the flowering of Coffea arabica L. III. Various phenomena associated with the dormancy of coffee flower buds. Portugaliae Acta Biologica, v.5, p.25-44, 1957.

MIGUEL, A.E.; MATIELLO, J.B.; CAMARGO, A.P.; ALMEIDA, S.R. de; GUIMARÃES, E.S. Efeitos da arborização do cafezal com Grevillea robusta nas temperaturas do ar e umidade do solo. Parte II. In: CONGRESSO BRASILEIRO DE PESQUISAS CAFEEIRAS, 21., 1995, Caxambu. Anais. Caxambu: Mara/Procafé, 1995. p.55-60.

PAULO, E.M.; BERTON, R.S.; CAVICHIOLI, J.C.; BULISANI, E.A.; KASAI, F.S. Produtividade do café Apoatã em consórcio com leguminosas na região da Alta Paulista. Bragantia, v.60, p.195-199, 2001.

RAMÍREZ, L.G. Producción del café (Coffea arabica) bajo diferentes niveles de fertilización con y sin sombra de Erythrina poeppigiana (Walpers) O.F. Cook. In: WESTLEY, S.B.; POWELL, M.H. (Ed.). Erythrina in the new and old worlds. Paia, Hawaii: Nitrogen Fixing Tree Association, 1993. p.121-124.

SEIFFERT, N.F.; MONDARDO, E.; SALERNO, A.R.; MIRANDA, M. O potencial do guandu: uma leguminosa tropical, rústica, que produz proteína para o uso humano e animal. Agropecuária Catarinense, v.4, p.18-29, 1988.

SUÁREZ DE CASTRO, F.; MONTENEGRO, L.; AVILES, P.C.; MORENO, M.; BOLAÑOS, M. Efecto del sombrío en los primeros años de vida de un cafetal. Café, v.3, p.81-102, 1961.

VAAST, P.; HARMAND, J.-M. Importance des systèmes agroforestiers dans la production de café en Amérique Centrale et au Mexique. Recherche et Caféiculture, p.34-43, 2002.

WILLEY, R.W. The use of shade in coffee, cocoa and tea. Horticultural Abstracts, v.45, p.791-798, 1975. 